\title{
How well-being and involvement fit into the commitment to children's rights
}

\section{Ferre Laevers | Bart Declercq}

Centre for Experiential Education, University of Leuven, Leuven, Belgium

\section{Correspondence}

Ferre Laevers, Centre for Experiential

Education, KU Leuven, Schapenstraat 34, bus 3776, 3000 Leuven, Belgium

Email: ferre.laevers@kuleuven.be

\begin{abstract}
The theme of children's rights is receiving more attention than ever. Although the manifest on this topic was universally agreed decades ago, it is obvious that the ambitions expressed in it are far from being implemented. In this article, we explore how the experiential approach can contribute to the process of clarification and operationalisation for children between birth and the age of six. The central idea is that well-being and involvement as process variables can provide a measure for the degree to which children's rights are met, especially in educational settings. The scanning and screening are highlighted as procedures to assess levels of well-being and involvement. The data yielded provide a rich source for interventions both at the individual and group level. Next, we review what we can learn from research where these process-variables have been observed, that is their levels and the factors in the (learning) environment that determine them. In the closing discussion, we hold the insights on well-being and involvement against the light of "children's rights" and articulate implications for practice, research and policy.
\end{abstract}

\section{1 | INTRODUCTION}

Attention to children's' rights has recently become paramount, with their needs to be placed at the centre of any educational initiative (European Commission, Directorate-General for Education \& Culture, 2014). This is, however, an ambitious and challenging goal that confronts us with a series of questions. What is needed to redesign the role of children from that of passive recipients of care and educational support to active participants? How can we give children a voice and ownership over their learning journeys? How can we capture and value the 
contributions of all children, including babies, in the field of early childhood education? Attempts to involve young children in the evaluation of the quality of educational practices are rare. In this article, we explore and document how the process-oriented approach can fill this gap. The article starts with an introduction to the experiential approach and an outline of the key variables well-being and involvement (Laevers 1994, 1997, 2005, 2011). The procedures to assess these are explained and research results presented, as well as their implications for educational practice. To conclude, the insights are held against the light of children's rights and critically discussed.

\section{2 | THE EXPERIENTIAL APPROACH}

Fifteen years ago in its search of a way to respond to the paragraph on children's rights in its mission statement, the Flemish agency for the childcare sector in Flanders, Kind en Gezin, added a new dimension to its assessment of quality: the perspective of the child. Capitalising on the expertise developed at the Centre for Experiential Education, a project was launched in 2003, resulting in the design of the "Self Evaluation Instrument for Care Settings" (SiCs). Its underlying assumption was that if we could not expect babies and toddlers to tell us how happy they were with the educational arrangement we offered, it was our role to check in a systematic way how each child was experiencing "being in an early childhood setting." This is the closest we can get in our endeavour to make young children equal partners in the circular process that shapes the educational environment. To achieve this goal, we depend on the particular disposition that was conceptualised and cultivated in the "experiential movement" launched by Carl Rogers and his collaborator Eugene Gendlin which encompasses the role taking capacity that allows us to get into the skin of the other, to get in touch with the other side and to imagine how he or she is experiencing a particular situation. In this process, we mobilise our intuitive intelligence by opening or lending a part of our personal stream of experience to be filled by the experience of the other. What we obtain from this advanced form of "empathy" covers all dimensions: feelings, perceptions and cognition and the conative (motives and intentions).

\section{3 | WELL-BEING AND INVOLVEMENT}

The experiential way to approach educational contexts has proven to be fruitful. Whatever was conceptualised and operationalised in the Leuven Experiential Education project, the key has always been to take the perspective of the participants-children and adults-into account and from there try to understand how the pedagogical environment can be optimised. The overall goal was to develop the unique potential of each person, strengthen social-emotional health, the exploratory drive, the growth of talents and an attitude of "linkedness" with oneself, the others, society, the material world, nature and the cosmic entity, representing the ethical dimension. This learning journey ${ }^{1}$ in close collaboration with practitioners led to a major breakthrough in the mid-1980s. Although the identification of the "content" of the experience (in terms of mental activity, perceptions and cognitions) has its value, consideration of the "quality" of children's experiences proved to be more practical with respect to monitoring quality. Hence, the most economic and conclusive way to estimate the quality of any educational setting was to focus on the child's degree of "emotional well-being" and level of "involvement." Both are process-variables, as they capture how a person experiences a particular situation instead of focusing on the learning environment or the outcome.

Well-being is defined as a state in which one feels at ease, shows spontaneity, is self-confident and enjoys its presence and interactions with others (Laevers, Moons, \& Declercq, 2013). The levels of well-being tell us how children are thriving in the area of social-emotional development and how far their mental health is secured. This is based on the rationale that well-being reflects how their basic needs, such as their physical needs, need for tenderness and affection, for safety and clarity and for social recognition, to feel competent and the need for 
meaning in life (including moral values) are fulfilled as a result of both the children's actions and the quality of the (educational) environment.

Involvement signals how children are concentrated, absorbed and fascinated, how they are engaged in activities and operating at the very limits of their capabilities. Congruent with Csiksentmihayli's (1979) "state of flow," it is considered to be indispensable for deep-level-learning. Well-being and involvement can be seen as measures for the power of the learning environment. But they are also the keys to an approach that takes into account children's perspective in a radical way. In relation to the central theme of this article, we can therefore conclude that it is a fundamental right for children to experience "well-being" and "involvement" in whatever educational setting they find themselves. Indeed, when these prove to be low, the analysis can reveal that factors and experiences outside the setting play a role.

Before pursuing our reasoning, a possible misunderstanding must be taken out of the way. Well-being and involvement is not something "done to children". They flag us that children succeed in interacting with their surroundings in a way that fulfills their needs. They have an active role in it. Sometimes it means that we have to help them to develop the dispositions and competences to be able to succeed.

\section{4 | ASSESSMENT OF WELL-BEING AND INVOLVEMENT}

If the assessment of well-being and involvement is to reveal how far the fundamental rights of children are respected, we need tools to map how children are doing. For that purpose, two instruments were developed, using a five-point scale: the Leuven Involvement Scale and the Leuven Well-being Scale. They are available in two variants, depending on their purpose and the procedure for data collection.

\section{1 | The screening procedure}

This technique is used by practitioners to periodically assess the well-being and involvement of all individual children. It is the "spinal cord" in the Process-Oriented Child Monitoring System (POMS) (Laevers, 2012; Laevers, Moons, \& Declercq, 2013). This approach exploits the wealth of information or images that the practitioners have stored about each of the children over a period of two or three weeks which are used to see how they experienced the provided context. The group screening starts from two variables-well-being and involvement-and after completion produces a shortlist of children who need more attention. From there, extra observations and collection of information are undertaken for those who are in the red zone (with at least one score below 3 ) or in the amber zone (with at least one score at level 3). The nature of the two process variables guarantees that both the process of socio-emotional development and the process of development of cognition and competences are covered. A screening is carried out three times a year. Typical features of the process variables are that they signal potential problems at the earliest stage and provide feedback about the impact of interventions. The identification of children who do not thrive is the main entrance. In contrast, a product-oriented approach focuses on achievement and would label children who are not meeting the norm level for the age group as "in need." In the process-oriented approach, children who are truly engaging in activities in the area for which they are not meeting the norm (such as motor development, language, social competence ...) will not appear on the shortlist of children needing remediation. For example, children with less developed fine motor skills who respond well to an offer of materials and to activities mobilising this area of development will not be labelled "endangered" despite their poor developmental level. This takes us away from the deficit model. Furthermore, it becomes clear how gifted and talented children are ignored or neglected in the product-oriented approach. While too many of these children are not spotted on the product-oriented radar, they can nevertheless in need of a more challenging environment. A gifted child causing no concern in terms of achievement will get full attention in a process-oriented approach when we realise the extent of the child's boredom. 


\section{2 | The scanning procedure}

Next to the screening, a procedure was developed to assess levels of well-being and involvement in settings at a certain moment of the day. In this "scanning" technique, data are collected through the observation of a sample of seven to ten children from a group during consecutive two-minute episodes per child. A score on the well-being and involvement scale is assigned during each episode. A scanning cycle takes about 25 minutes for 10 observed children. It is particularly useful for: (i) training purposes, where a trainer with two or three trainees can jointly make scanning rounds in a group and share their scores after each cycle; (ii) research, where a few scanning cycles per group as a sample provide a view on the quality and (iii) self-evaluation of quality by the settings. The latter was standardised in the Self-evaluation Instrument for Care Settings (SiCs) (Laevers, 2007, 2008).

The screening technique was designed as a tool for the practitioners. It helps to find out how each of the children in the group is doing, based on a longer period of observation, and to draw portraits of individual children which lead to the necessary interventions to raise the levels of well-being and/or involvement. The results of the scannings take measures at the level of the practice in general, but they are less powerful to come up with interventions at the individual level. Where one needs frequent contact with children for the screening, the main advantage for the scanning is that (i) it is cost-effective to obtain a view of the well-being and involvement in several groups, (ii) it rates well-being and involvement in the context where the practitioner is interacting with the group and (iii) the reliability of the data can be monitored because an external person (from the staff, a coach or a researcher) performs the observations. Although the screening technique is most powerful because it brings practitioners closer to each of the children, the scanning can be seen as a very practical way of taking a kind of "snapshot" of how the setting is performing in terms of quality at a certain moment. Fitting into a pre- and a posttest design, it is particularly useful in the context of intervention studies.

\section{5 | HOW ARE CHILDREN DOING?}

The scanning procedure has been used in a series of studies (SiCs, Milton Keynes, Korein, Every child well in his skin, (Laevers, 2017). MeMoQ, funded by Kind \& Gezin, is the most recent large scale research project in Flanders using this technique (MemoQ, 2015). MeMoQ stands for Measurement and Monitoring of Quality in early childhood settings (0-3 years). It ran from 2014 to 2017. The output consisted of a pedagogical framework, a scientific instrument, a baseline measurement, a monitoring instrument for the inspection and a self-evaluation-instrument for early childhood settings. A first measurement (or baseline assessment) was conducted from September 2015 to April 2016 on a representative sample of 200 home-based and 200 centre-based settings for 0-3-year-olds in Flanders. Each setting was visited during one morning. Levels of well-being and involvement were assessed using the scanning method, interactions between children and adults were registered using CLASS Infant ${ }^{\circledR}$ and CLASS $®$ Toddler $^{2}$ (La Paro, Hamre \& Pianta, 2012) and the quality of the environment was rated with earlier scales adapted for this purpose. The observations were supplemented with a questionnaire for parents and a questionnaire for the setting manager to collect information about input and context elements. The aim was to measure the process quality and to set a baseline (Hulpia et al., 2016) in view of a longitudinal perspective (Vandenbroeck et al. 2016). In total, 6578 individual assessments of well-being and involvement were collected, spread over 400 settings. ${ }^{3}$ In every setting, one observer collected data in one group. During four predefined observation rounds spread out over the morning, 5 children per round were assessed for well-being and involvement. In total, a maximum of 20 children per group were observed during the morning. Based on these scores, a mean score per group was calculated. In total, 2980 scores (45\%) were collected in home-based settings and 3598 (55\%) in centre-based settings. The data provide a robust indication of how children are doing in the Flemish early childhood settings. The overall mean score for well-being was 3.36 and 2.72 for involvement. Can we be satisfied with these scores? To make that kind of judgement, we built up a reasoning in order to mark the line that could be considered as "a 
minimal acceptable" result at the group level. To answer this question, it was crucial to understand what the levels meant for children psychologically, since a statistical approach would never provide a solution. The norm is what we believe to be the quality that should be attained.

The Leuven involvement scale

\author{
$>1$ No activity \\ $>2$ Interrupted activity \\ $>3$ Activity without intensity \\ $>4$ Activity with intense moments \\ $>5$ Continuous intense activity
}

The Leuven well-being scale
$>1$ Outspoken signs of distress
$>2$ Signs of distress predominate
$>3$ A mixed picture, no outspoken signs
$>4$ Signs of enjoyment predominate
$>5$ Outspoken signs of enjoyment

Taking into account the scale levels (Table 1), we concluded that a score of 3.50 could be seen as the caesura. We can live with the idea that half a group would have been assigned a level 3 and the other half a level 4 . That would mean that children's well-being and involvement would have "a tendency to the positive side."

A first conclusion is that the settings are more effective in achieving higher levels of well-being than of involvement. The mean score for involvement (2.72) was clearly below our norm (3.50) and the mean score for well-being (3.36) approached the norm. About $30 \%$ of the groups were doing rather well in terms of well-being, whilst only $8 \%$ equalled that qualification for involvement. Most of the groups (63\%) had a mean for well-being between 3.00 and 3.49. In terms of involvement, $92 \%$ of the groups were below the criteria of "minimal acceptable score."

Relating these results to our statement that children are entitled to enjoy their stay in early childhood settings (in terms of well-being) and to be engaged in activity (in terms of involvement), we cannot be satisfied. In a former large scale research in Flanders (2007) the figures were more positive. In a sample of about 8000 children we recorded a mean level of 3.63 for well-being and of 3.32 for involvement. We do not expect the quality to have deteriorated since then. The most plausible explanation lays in the fact that in the research of 2007 those who

TAB LE 1 Mean scores for well-being and involvement per setting [ $N=400]$

\begin{tabular}{|c|c|c|c|c|c|c|c|}
\hline \multicolumn{8}{|c|}{ Well-being } \\
\hline & $1.50-1.99$ & $2.00-2.49$ & $2.50-2.99$ & $3.00-3.49$ & $3.50-3.99$ & $4.00-4.49$ & $4.50-5.0$ \\
\hline Number & & & 30 & 252 & 108 & 10 & \\
\hline$\%$ & & & 7.5 & 63 & 27 & 2.5 & \\
\hline Low vs high & $70.5 \%$ & & & & $29.5 \%$ & & \\
\hline \multicolumn{8}{|c|}{ Involvement } \\
\hline & $1.50-1.99$ & $2.00-2.49$ & $2.50-2.99$ & $3.00-3.49$ & $3.50-3.99$ & $4.00-4.49$ & $4.50-5.0$ \\
\hline Number & 31 & 105 & 150 & 82 & 26 & 6 & \\
\hline$\%$ & 7.7 & 26.3 & 37.6 & 20.6 & 6.5 & 1.4 & \\
\hline Low vs high & $92 \%$ & & & & $8 \%$ & & \\
\hline
\end{tabular}


TAB LE 2 Mean scores for Class Infant [ $\mathrm{N}=167]$ and Class Toddler [ $\mathrm{N}=233]$ per setting

\begin{tabular}{|lllllll} 
& & & & & Min. & Max. \\
\hline Infant [3-18 M] & Emotional support & 3.63 & .64 & 2.00 & 5.00 \\
\hline \multirow{2}{*}{ Toddler [18-36 M] } & Educational support & 2.45 & .78 & 1.04 & 4.54 \\
\hline & Emotional support & 3.60 & .60 & 1.52 & 4.79 \\
\hline & Educational support & 1.93 & .56 & 1.06 & 3.64 \\
\hline
\end{tabular}

participated volunteered to do so. We had a non-representative sample whilst the The MeMoQ-research (2016) was a representative sample.

\section{IMPLICATIONS FOR EDUCATIONAL PRACTICE}

There is ample evidence from research that well-being and involvement are linked to the particular characteristics of the learning environment captured by internationally recognised frameworks, such as the CLASS. The recent data of the MeMoQ project (Table 2) reveal that, whilst the dimension of emotional support obtains a rather good rate, the quality of the educational support in the interactions with children is poor. This is the case for both the infants and the toddlers and is in line with other research using the CLASS (Fukking, 2017; La Paro, Wiliamson, \& Hatfield, 2014; Slot, 2014; Thomason \& La Paro, 2009).

Table 3 provides an indication of the relation between well-being and involvement and the characteristics of the learning environment. We note that there is a good to high correlation between all components of quality. Higher levels of well-being and involvement are associated with a better quality of emotional and educational support and of the characteristics of the environment (such as the space for children to take initiatives and the richness of the offered materials and activities).

These results can be linked with the theme of this article. If children have the right to experience a certain degree of well-being and involvement in early childhood settings, we can add that they have the right to encounter and be part of an educational approach that creates the necessary conditions for both well-being and involvement. Children are entitled to be welcomed in an environment where positive relations and a good climate reign.

TAB LE 3 Correlation between well-being, involvement, emotional support, educational support and the environment

\begin{tabular}{|c|c|c|c|c|c|c|c|}
\hline & Well-being & Involvement & $\begin{array}{l}\text { Emotional } \\
\text { support } \\
\text { Infant }\end{array}$ & $\begin{array}{l}\text { Educational } \\
\text { support } \\
\text { Infant }\end{array}$ & $\begin{array}{l}\text { Emotional } \\
\text { support } \\
\text { Toddler }\end{array}$ & $\begin{array}{l}\text { Educational } \\
\text { support } \\
\text { Toddler }\end{array}$ & Environment \\
\hline Well-being & 1 & $0.727^{* *}$ & $0.486^{* *}$ & $0.470^{* *}$ & $0.439^{* *}$ & $0.400^{* *}$ & $0.281^{* *}$ \\
\hline Involvement & & 1 & $0.472^{* *}$ & $0.446^{* *}$ & $0.451^{* *}$ & $0.358^{* *}$ & $0.348^{* *}$ \\
\hline $\begin{array}{l}\text { Emotional } \\
\text { support Infant }\end{array}$ & & & 1 & $0.785^{* *}$ & & & $0.589^{* *}$ \\
\hline $\begin{array}{l}\text { Educational } \\
\text { supportInfant }\end{array}$ & & & & 1 & & & $0.596^{* *}$ \\
\hline $\begin{array}{l}\text { Emotional } \\
\text { support Toddler }\end{array}$ & & & & & 1 & $0.698^{* *}$ & $0.639^{* *}$ \\
\hline $\begin{array}{l}\text { Educational } \\
\text { support Toddler }\end{array}$ & & & & & & 1 & $0.486^{* *}$ \\
\hline Environment & & & & & & & 1 \\
\hline
\end{tabular}


They must find well-equipped areas and rich materials and a generous offer of challenging activities. Room for initiatives such as the freedom to choose, participation in practical matters and in the setting of rules and agreements, etc. should be evident. They must also find an organisation of time and place that offers a clear but flexible plan of the day geared to their needs, fluent transitions in activities, optimal use of the adults present in the room, appropriate grouping, etc... And maybe above all, an engaged and empathic adult who takes into account children's feelings and needs, empowering them by stimulating interventions and supporting autonomy (Laevers, Debruyckere, Silkens \& Snoeck, 2005).

Based on a myriad of observations and reflections with early years practitioners and teachers, a checklist was made available, introducing five factors that have proven to be powerful in the pursuit of higher levels of wellbeing and involvement. These factors are: the offer, the group climate, room for initiative, organisation and the guidance style]. They are integrated in the SiCs manual (Laevers, Declercq \& Silkens, 2007). At least two intervention studies brought evidence on the impact of initiatives inspired by the process-oriented approach. The Milton Keynes project (Laevers, Declercq, \& Buyse, 2011) conducted in settings with children aged from 0 to 6 reported a significant gain in both well-being and involvement: for the first, an increase from 3.34 to 3.74 and for the latter from 2.94 to 3.47 over a period of a year. The sample consisted of 50 groups and about 500 children. In the recent project in collaboration with Korein and Onderwijs Maak Je Samen (Declercq \& Laevers, 2017), the results from pre- to post-test revealed a significant growth in well-being from 3.59 to 3.78 and in involvement, from 3.24 to 3.50 over a period of 9 months.

\section{7 | CHILDREN'S RIGHTS AND EMANCIPATION}

The common view on children's rights promotes a respectful rapport with children. With well-being and involvement we added user-friendly criteria to find out to what degree we had succeeded in creating that kind of rapport. Although we can never guarantee a certain level of well-being and involvement for every child because of factors out of our reach, both indicators can serve as touchstones in our endeavour to meet children's basic needs. From these process-indicators, we described the kind of environment children were entitled to find and we, as adults, had to strive for if we took well-being and involvement seriously.

However, a reflection beyond this operational level is needed to broaden the scope. A reference to historical processes that accompanied the articulation and implementation of human rights in the past is most enlightening, especially the case for the rights of Blacks and women. Together with the astonishing fact that it took so long to obtain a breakthrough in these fields, we need to introduce the concept of "images" for a deeper understanding of these processes. The acquisition of rights is about how people view one another. The major factor lays between the ears. The image one holds of the other (suppressed) party explains one's behaviour. An analysis of this struggle against belittling images that became poignant with the Sufragettes at the beginning of the 20th century reveals that men had an image of women that excluded real participation in the decision making process of a country. Typical for that period was the quote of a member of Parliament in England at the beginning of the century, warning his fellow members that after the right to vote, one must fear the unthinkable: having women in Parliament as representatives. The end of the world! Indeed this was only one of the limited views on women affecting all areas of women's lives. The acquisition of rights is a process of transition from one "image of the other"-with a conviction of the lack of competence to act as an autonomous person, evolving to a "new image" in which the other is perceived as an equal being, entitled to the same privileges as any other person in society. To this, we can add two insights. To understand the reluctance for change in the area of rights, we must consider that the common view of men about women was shared by the women themselves. Women standing up for their rights were felt by other women as a threat for their "stable" way of life. Militant women, fighting on the barricades, were seen as the enemy. That brings us to the second conclusion: the installation of any rights for any group of people must be seen as a process of emancipation. It is a struggle 
in which all parties must evolve not only from a fixed mindset about "who the other is," but also from their selfimage. This transformation process always entails a loss of power for one party, but a gain for all parties where a positive, unconditional relation can take shape.

What about children's rights? This visit to the historical perspective related to human rights can help us to realise what is at stake. We must envision that the recognition of children's rights goes beyond "being nice to kids" or ends with the abolishment of child labour. If we focus on well-being and involvement and even our target to a mean score of 3.00 as a measure of the quality of practice, we can conclude that too many children do not receive what they need in the early years settings in Flanders, as assessed by the MeMoQ project. Where $7.5 \%$ of the groups score too low for well-being, involvement, with $71.6 \%$ below level 3.00, is a cause for concern. Some may consider that the social emotional dimension is more important than the area of cognitive development. We then have to bring up that a failure to bring a child into that highly rewarding "state of flow"-facing instead, boredom-is devastating. Every open-minded view on children will ascertain that, from close after birth, babies display a strong exploratory drive that pushes them to get in touch with their surroundings. It is an immense source of energy that culminates in the type of concentration and fascination we call "involvement"-a phenomenon already spotted and valued by Maria Montessori. It is in this quality that we need to engender deep-level-learning. At the same time, the experiences of involvement bounce back onto children's self-image and feed their sense of selfesteem, awareness of competence and perception of talent.

\section{A CIRCULAR PROCESS}

We need to go even deeper in our reflection. Raising the levels of involvement in children will have to go along with a process of emancipation in which both children and adults are involved. It will change our image of children, as happened with women and Blacks. In all these cases, the change entails a growing awareness of the capacities of the other, evolving away from a huge underestimation of the competencies of children towards a strong belief in their level of self-organisation. In practice, it means: creating an educational context with a high degree of child participation, also in the process of decision making. How far are we on this path? The following dialogue helps us to understand how challenging the respect for children's rights can be for adults.

Ch.: "I can't draw this!"

A.: "Yes, everybody can."

Ch.: "No, I can only make a scarf"!

A.: "No, gloves are easy as well."

Ch.: "No, only a scarf."

A.: "Come on, make an effort. The other children can do it, why can't you"?

We recognise the dialogue as part of an activity where children, first in a group, were guided to explore winter clothing. In an open conversation children could describe what they felt and saw, or even talk about experiences associated with winter time. As planned by the adult, the activity is followed by expression. Children have to draw a particular item that has been discussed. We see that the child in the observation does not want to stick to the task, but prefers to draw another garment. From the point of view of the adult we can understand that activities must meet certain goals and that the gloves probably have a complexity that is lacking in the scarf. But what is happening here is a display of the kind of rapport adults tend to have with children. One in which it is taken for granted that I, as an adult, can decide what this four-year-old will draw. The key question is then: if we really want to establish a relation of reciprocity, why would we argue in this case and question the initiative proposed by the child? Accepting children's rights means that we accept the process of emancipation that goes with it. The child's experience in this dialogue will not be beneficial for the development of an autonomous state of mind, including taking responsibility for one's actions. What do we have to lose? The situation would have been slightly more complex if the child did not 
want to draw at all. But here there is no rejection of the task as a whole by the child. So again: what do we have to lose? Will drawing the scarf (with involvement) instead of the gloves (reluctantly) have any consequences for later? The farthest the adult could have gone would have been to ask the child why he or she preferred the scarf. And if the answer would have been "because it is too difficult," the adult could ask "if getting some help would be a solution ...." If not: no harm done.

\section{9 | CLOSING REFLECTIONS}

Our exploration of the intersection between the experiential approach and the theme of children's rights has led to the conclusion that taking well-being and involvement as indicators of quality at the same time seems to be a secure way to make sure children's rights are respected. With this comes the awareness of critical factors that should guide the design of the learning environment. Up front stands the quality of interactions and in particular the adult's style, including sensitivity, stimulating interventions and supporting autonomy (Laevers \& Heylen, 2003). But also the offer of a rich environment responding to children's exploratory drive combined with an open framework that allows children to be entrepreneurial. As an overarching quality, we can add a positive group climate in which diversity is welcomed. Taking these touchstones into account we can conclude that more must be done to raise levels of well-being and even more for involvement. Both the data from screenings and scannings provide a rich basis for this reflection. With well-being and involvement as their guide, it is within the reach of most practitioners to find out "where" and "when" the lower scores are observed and from there what kind of initiatives could improve their practice.

In a next move, we must realise that the implementation of the statements on children's rights is not an easy journey. It is a process in which both the adults and children get another view of themselves and of the other, meaning that, without a development on both sides, the emancipation of the child will never be a fact. This is gained step by step in a circular process: the gain on one side (the adult's perception of the child) leads to a gain on the other (the child's perception) and this facilitates a gain again on the adult's side. This openness for the richness of every human being is the basis for another level of interaction. As a result, both parties get closer to one another and thus can mean more for their mutual development.

Where we started with the idea that an experiential approach could indirectly provide the guidelines we need when children are not able to voice their concerns and wishes, we must not let this argument dominate our initiatives. The process of emancipation will lead to a lowering of the age when children can be involved in the evaluation of the context we provide as educators. A recent experience in the context of the intervention study "Elk kind goed in zijn vel (Every child well in his skin)" (Laevers, Stas \& Van Cleynenbreugel, 2018) has revealed that children aged $2 \frac{1}{2}-3$ years were capable of rating their satisfaction in relation to several aspects of their daily experience, facilitated by a set of illustrations and some support from an adult.

Finally, we must look at this topic in a longitudinal perspective. A first misunderstanding would be to expect that children's rights are well cared for when we look at the pre-primary, primary and secondary levels of education. Although we may expect that at that age children can be more outspoken, we must conclude from the levels of involvement that we are far from the reciprocity and respect of basic children's rights. With a mean score of 2.60 for involvement in the first two years of secondary school reported in the Procrustes study (Van Maele, Michalek, Engels, Laevers, Lombaerts, \& Van Houtte, 2015), we can conclude that the learning environments do not succeed in supporting youngsters in the development of their talents. We must hope that the innovative and ground-breaking initiatives in a growing number of schools will help to turn the tide. In the meantime: let us do what we can to make sure the youngest children obtain what they need to become emotionally strong, inquisitive, entrepreneurial and socially-engaged persons. This will be a precious gift to the teachers in the educational settings following the early years. 


\section{ENDNOTES}

${ }^{1}$ This project began in 1976 when a group of 12 pre-primary teachers engaged in a process of observation, reflection and action laying the foundation of the Leuven experiential model.

${ }^{2}$ CLASS ${ }^{\circ}$ stands for the Classroom Assessment Scoring System. It's a scientific tool that measures the quality of interactions between practitioners and children. It is developed at the University of Virginia's Center for Advanced Studies in Teaching and Learning. There are several variants of the CLASS ${ }^{\circledR}$-tool depending the age levels of children. The CLASS Infant ${ }^{\circ}$ covers children from birth to 18 months, the CLASS ${ }^{\circ}$ Toddler covers children from 15 to 36 months.

${ }^{3}$ In most cases; only one group was observed in the stratified sample of settings.

\section{REFERENCES}

Csikszentmihayli, M. (1979). The concept of flow. In B. Sutton-Smith (Ed.), Play and learning. New York: Gardner Press.

Declercq, B., \& Laevers, F. (2017). Procesgericht werken aan kwaliteit in de kinderopvang. Ontwikkeling van hulpmiddelen, strategieën en bewijs voor een effectieve inzet in de Nederlandse context. Rapportage van het flankerend onderzoek. Leuven: ExpertiseCentrum ErvaringsGericht Onderwijs, KULeuven.

Early Excellence. (2015). Reflect good baseline assessment practice: Choose. Huddersfield: EExBA. Retrieved from https:// earlyexcellence.com/wp-content/uploads/2015/05/reflect-good-baseline-assessment-practice-choose-eexba.pdf.

European Commission, Directorate-General for Education and Culture. (2014). Proposal for key principles of a Quality Framework for Early Childhood Education and Care. Brussels: European Commission. Retrieved from https://eurochild.org/fileadmin/public/05_Library/Thematic_priorities/04_Early_Years/European_Union/ ecec-quality-framework_en.pdf

Fukking, R. (Red.). (2017). De Nederlandse kinderopvang in wetenschappelijk perspectief. Amsterdam: SWP.

Hulpia, H., Vandenbroeck, M., Daems, M., Declercq, B., Janssen, J., VanCleynenbreugel, C., \& Laevers, F. (2016). MeMoQ Deelrapport 10. Emotionele en educatieve ondersteuning in de nulmeting. Brussel-Gent-Leuven: Kind \& Gezin-UGentKU Leuven. Retrieved from https://www.kindengezin.be/img/emotionele-educatieve-ondersteuning-rapport.pdf

La Paro, K., Hamre, B. K., \& Pianta, R. C. (2012). Classroom assessment scoring system. Manual Toddler. Baltimore: Brookes Publishing.

La Paro, K., Hamre, B. K., Pianta, R. C., \& LoCasale-Crouch, J. (2014). Classroom assessment scoring system. Manual Infant. Baltimore: Brookes Publishing.

La Paro, K. M., Wiliamson, A. C., \& Hatfield, B. (2014). Assessing quality in toddler classrooms using the CLASS Toddler and the ITERS-R. Early Education and Development, 25, 875-893.

Laevers, F. (1994). The innovative project Experiential Education and the definition of quality in education. In F. Laevers (Ed.), Defining and assessing quality in early childhood education (pp. 159-172). Leuven: Studia Paedagogica.

Laevers, F. (1997). Assessing the quality of childcare provision: "Involvement" as criterion. In: Settings in interaction. Researching Early Childhood, 3, 151-165.

Laevers, F. (2005). The curriculum as means to raise the quality of ECE. Implications for policy. European Early Childhood Education Research Journal, 13, 17-30. https://doi.org/10.1080/13502930585209531.

Laevers, F. (Ed.) (2007). Well-being and involvement in care settings. A process-oriented self-evaluation instrument (SiCs). Brussel: Kind \& Gezin. Retrieved from www.kindengezin.be/-img/sics-ziko-manual.pdf

Laevers, F. (2011). Experiential education: Making care and education more effective through well-being and involvement. In J. Bennett (Ed.), Canadian encyclopaedia on early childhood development. Retrieved from www.child-encyclopedia.com/sites/default/files/dossiers-complets/en/child-care-early-childhood-education-and-care.pdf

Laevers, F. (Ed.). (2012). My profile. Sharing observations with parents, in the early years. Leuven: Cego Pubishers.

Laevers, F. (2017). How are children doing in ECEC? Monitoring quality within a process-oriented approach. In N. Klinkhammer, B. Schäfer, D. Harring, \& A. Gwinner (Eds.), Monitoring quality in early childhood education and careApproaches and experiences from selected countries. Munich: German Youth Institute Department Children and Childcare. Retrieved from www.dji.de/fileadmin/user_upload/bibs2017/Monitoring_Sammelband_E_final.pdf

Laevers, F., Debruyckere, G., Silkens, K., \& Snoeck, G. (2005). Observation of well-being and involvement in babies and toddlers. A video-training pack with manual. Leuven: Cego Publishers.

Laevers, F., Declercq, B., \& Buyse, E. (2011). Raising levels of well-being and involvement in Milton Keynes. Centrum ervaringsGericht Onderwijs: Preschool Settings Internal report. Leuven.

Laevers, F., Declercq, B., Marin, C., Moons, J., \& Stanton, F. (2011). Observing involvement in children from hirth to 6 years. A training pack [DVD + Manual]. Leuven: Cego Pubishers.

Laevers, F., Declercq, B., \& Silkens, K. (2007). Raising the quality of foundation stage provision. Report Phase 1: Kent PSA project 2005-2008. Evaluation of the Notes of Visit 2008. Leuven: Centrum ErvaringsGericht Onderwijs. 
Laevers, F. \& Heylen, L. (Eds.) (2003). Involvement of children and teacher style. Insights from an international study on experiential education. Leuven: Studia Paedagogica.

Laevers, F., Moons, J., \& Declercq, B. (2013). A process-oriented monitoring system for the arly years [POMS]. Leuven: CEGO Pubishers.

Laevers, F., Stas, T., \& VanCleynenbreugel, C. (2018). Elk kind goed in zijn vel (Every child well in his skin). Implementatie en effectonderzoek van een interventiepakket voor de preventie van emotionele problemen en zelfdoding. Rapportage van het flankerend onderzoek. Leuven: ExpertiseCentrum ErvaringsGericht Onderwijs, KU Leuven.

MemoQ. (2014). Naar een pedagogisch raamwerk. Nota ter discussie op de klankbordgroep van 30/01/2014 (intern document). Leuven: Centrum ErvaringsGericht Onderwijs. [Measurement and Monitoring Quality in the Child Care: towards a pedagogical framework].

MemoQ. (2015). A pedagogical framework for childcare for babies and toddlers. Brussel: Kind \& gezin. Retrieved from www. kindengezin.be/img/pedagogische-raamwerk-engelseversie.pdf

Slot, P. L. (2014). Early childhood education and care in the Netherlands. Quality, curriculum, and relations with child development. Utrecht: Riderprint. Retrieved from www.sociaalwerknederland.nl/?file=10614\&m=1418746717\&action=file.download

Thomason, A. C., \& La Paro, K. M. (2009). Measuring the quality of teacher-child interactions in toddler child care. Early Education and Development, 20, 285-304.

Van Maele, D., Michalek, N., Engels, N., Laevers, F., Lombaerts, K., \& Van Houtte, M. (2015). Gender op school. Meer dan een jongens-meisjeskwestie. Tielt: LannooCampus.

Vandenbroeck, M., Laevers, F., Hulpia, H., Daems, M., Declercq, B., Janssen, J., \& VanCleynenbreugel, C. (2016). MeMoQ Deelrapport 14. Samenvatting van de nulmeting. Brussel-Gent-Leuven: Kind en Gezin-UGent-KU Leuven. Retrieved from www.kindengezin.be/img/resultaten-nulmeting-samenvatting-rapport.pdf

How to cite this article: Laevers F, Declercq B. How well-being and involvement fit into the commitment to children's rights. Eur J Educ. 2018;53:325-335. https://doi.org/10.1111/ejed.12286 